\title{
Leadership Behaviour and Organisational Effectiveness in Post-Primary Schools
}

\author{
Fasanmi Success Ayodeji \\ Department of Educational Management, Obafemi Awolowo University, Ile-Ife, Nigeria \\ Email address: \\ safasanmi@oauife.edu.ng \\ To cite this article: \\ Fasanmi Success Ayodeji. Leadership Behaviour and Organisational Effectiveness in Post-Primary Schools. International Journal of \\ Secondary Education. Vol. 9, No. 1, 2021, pp. 26-32. doi: 10.11648/j.ijsedu.20210901.14
}

Received: December 19, 2020; Accepted: January 4, 2021; Published: March 10, 2021

\begin{abstract}
The study investigated the influence of Leadership Behaviour on Organisational Effectiveness in Secondary Schools in some selected schools in Ekiti State, a south-western state in Nigeria. The research design used was the descriptive research of the survey type. Subjects used for the study were 105 teachers including principals. The data were collected using a Leadership Behaviour and Organizational Effectiveness Questionnaire and Teacher's Perception of Principal's Leadership Behaviour Questionnaire. Five hypotheses were proposed and tested using chi-square statistical analysis. The results were held significant at 0.05 levels. The finding showed that there was a significant relationship between leadership behaviour and organizational effectiveness. The outcome of the research further revealed a significant difference between the qualification of leaders and their behaviour towards organizational effectiveness with no significant difference between the perception of leadership behaviour by teachers and principals.It was concluded from the results of this study that the sex of a leader goes a long way in determining the type of leadership behaviour he/she exhibits and that the positive perception of teachers about the principal will add more to the teachers' efficiency in that they will be psychologically balanced and disposed to do any work assigned to them by the school authority. Based on the results of the study it was recommended that the School Principal should recognize the fact that their interpersonal behaviour is very important in their daily interaction with teachers towards enhancing School effectiveness. They must be accommodating and sensitive to the needs and problems of their teachers.
\end{abstract}

Keywords: Leadership, Leadership Behavior, Organisational Effectiveness

\section{Introduction}

Leadership role is a must in any organization either small or large. It is needed in all facets of life be it health, politics, education, business or social institution. Leadership behaviour in an organization is one of the factors that play a significant role in enhancing or retarding the interest and commitment of the individuals in the organization. A leader occupies a central position in any setting. It is the leader that dictates the pace of an organization. He plans, organizes, dictates, supervises, coordinates and controls all affairs in the institution. He must ensure that the desired goals of the organization are achieved. In the school context, the Leader determines to a large extent the effectiveness of the School system. Schools as a part of the National education system certainly require serious attention and management. Therefore, to ensure rapid development and open societal change, school leadership requires more creative, innovative and dynamic abilities. [11]

In all organizations, there must be somebody or group of people to direct resources including employees, money, materials and equipment towards achieving organizational goals and maintaining standards. [9] Leaders are people who are supposed to be 'super -visionary' in order to effectively play the role of a supervisor in their respective organizations. They super - see good things and even other good hidden variables that are not visible to the rest of the people they are with. The leader is like a train head which guides the other coaches to move on the rail. They give direction. If it deflects, the rest of the coaches will also de-rail and the results will be devastating. It has become increasingly necessary that in order to be effective and have good followers, school leaders will have to shift from the conventional way and embrace a new approach. This is in line with the submission that Principals who are merely waiting and too adhering to bureaucratic rules, think structurally and do not dare to 
innovate to match the demands of their communities, will be abandoned by people. [11] This will require head teachers to know their followers and look out for their welfare, training teachers as a team, seeking self-improvement, making sound and timely decisions, seeking responsibility and taking responsibility for their actions.

From the foregoing, creativity can be said to be a vital element for a leader to be effective in the accomplishment of its goals. An effective leader is one who has a purpose and is able to influence his followers to enable them achieve that goal successfully. [3] The school is an organization under pressure in the twenty-first century where stakeholders and the media hold head teachers and teachers accountable for best results. Stakeholders expect head teachers and teachers to help their students to come out of school as holistic human beings, full of knowledge, skills, good attitudes and above all as critical thinkers and problem solvers. Hence, leadership in our schools is supposed to be creative, by looking at situations on hand and using various styles of leadership to bring teachers and students on board to achieve goals.

Leadership is a process where the administrators apply their influences over other behaviors in order to reach the goals of the organizations. [4] A school like any other organization needs leadership to sustain its continuous existence. In other words, if the school organization lacks a leader who possesses appropriate leadership behaviour, this may jeopardize its continuity as well as the achievement of desired goals. The leadership behaviour of a leader determines to a large extent their success in terms of overall administration of the school as well as the achievement of pre-determined goals. Leadership behaviour can either be appropriate or inappropriate. In a school organization, a leader can be said to be demonstrating inappropriate leadership behaviour when he employs the use of force, intimidation, harassment, embarrassment, humiliation, deceit and manipulation in the course of influencing the subordinate to achieve the goals of the school system. Observations revealed that the use of inappropriate leadership behaviour by school heads has generated suspicion, lack of cooperation, distrust and misunderstanding in the past between the subordinate and the super-ordinate. On the other hand, appropriate leadership behaviour which can be said to be exhibited by some school heads involves the use of leadership style in various situations so that maximum results are achieved. It must be emphasized there is no single best leadership style; the best leadership style is determined by the situation in which the leader finds himself. This type of leadership style Hence, the use of appropriate leadership behaviour becomes necessary with a view to ensuring the smooth running of the school.

The role of the principals of secondary schools in ensuring effectiveness is important because the leaders are considered to be a pace setter, they determine the quality of work and motivate the staff towards the accomplishment of the goals of the school system. The school leader's role were identified to include to include reviewing the organization's primary task; keeping this from being corrupted by the emotionality present in the organization; having a boundary-keeping function; avoiding the enactment of unconscious personal dynamics which interfere with institutional functioning; and paying attention to organizational dynamics. [10]

Leadership is expected to go with morality but it may not guarantee it, this implies that being in leadership does not make one outstanding in morals. It was noted that Leadership is not a moral concept. Leaders are like the rest of us: trustworthy and deceitful, cowardly and brave, greedy and generous. To assume that all leaders are good people is to be wilfully blind to the reality of the human condition, and it severely limits our scope for becoming more effective at leadership. [6]

A close observation of some school leaders reveals that while some of them lay emphasis on rules, procedures and principle and task of the school system neglecting the welfare of the staff, some other ones show concern only for the welfare of the staff at the expense of the task of organization. Against the above background, the school leader is expected to balance the two, while he emphasizes the rules, principles and procedures and the task of the organization, he must also ensure that proper attention is given to the welfare and plight of the workers. The integration of both will not only move the school forward it will as well ensure a good AuthorityStaff relationship in the school.

Supervision is an intervention that is provided by a senior member of a profession to a junior member or members of that same profession. [1] Supervision plays a vital role in creating a positive relationship between the leader and his subordinates and also provide ample evidence upon which assessment can be based For instance, for a principal to be successful in his daily administration and supervision he needs leadership capability. Thus, the leader in any school must have educational, social and psychological attributes in order to succeed on the job.

Teachers' behaviour is undergoing changes due to modernization, democracy and awareness created by the level of education as well as experience from environments. Therefore, leaders have to adopt ways of interacting with teachers to meet their social and psychological needs. Many teachers in Nigeria desire to partake in staff development programmes but for one reason or the other some principals have been found to be less supportive of their teachers' desire to run such programmes. Their leadership attitude to staff programmes contribute to organizational effectiveness as well as the achievement of organizational goals. Leadership that makes a difference is both position based (principal) and distributive (administrative team and teachers) but both are only indirectly related to student outcomes. [12]

Interpersonal relation in organizations is another factor that produces better and sustainable results. The result from the Human Relation Studies and Experiments of the 1950's [5] in the United States of America, tended to suggest that leadership based on mutual understanding between management and workers will achieve sustainable results. 


\section{Statement of Problem}

It is assumed that the success of a school depends to a considerable extent on the type of leadership behaviour it gets from its principal. The employees' morale needs to be improved and maintained. The responsibility of improving the workers morale lies greatly on the leaders. The school system is growing and developing in keeping pace with the leadership changes in the society. It is necessary and even important for the principal who is the agent of change to be equipped with the leadership behaviour that will make him effective and at the same time achieve these goals of the school.

The problem of this study therefore is to determine what relationship exists between the leadership behaviour of principals and organizational effectiveness and the extent to which their behaviour enhances staff performance and the consequent influence of staff performance on the students' academics in secondary schools in Irepodun/Ifelodun Local Government of Ekiti State. In addressing this problem, the following research questions were raised:

1. What is the Principal's Behaviour in Secondary Schools in Irepodun/Ifelodun Local Government Area of Ekiti State?

2. What is the level of organizational effectiveness in secondary schools in Irepodun/Ifelodun Local Government of Ekiti State?

3. What is the behaviour of Principals towards organizational effectiveness in secondary schools in Irepodun/Ifelodun Local Government?

\section{Purpose of the Study}

The purpose of the study is to find out the relationship between the behaviours of secondary school principals and organizational effectiveness in Ekiti State. The study also examined the extent to which there are variations in the relationship according to such factors as Age, Sex, Educational qualification, teaching experience, type of school (boarding/day) and location (urban/rural).

\section{Method}

This study was a descriptive research of the survey type. The population of the study consisted of all teachers and principals in the secondary schools in Irepodun/Ifelodun Local Government Area of Ekiti State. A total of five principals were selected from the five secondary schools out of the twelve secondary schools available in Irepodun/Ifelodun Local Government Area of Ekiti State. Twenty teachers were selected from each of the five schools. A purposive sampling technique was used based on the number of years of experience of principals selected. They must have spent a minimum of five years in their schools. The stratified random sampling technique was also used to group samples into male, female, age and experience etc. for the purpose of the study.
Two sets of instruments were used for the study. The first instrument was titled Leadership Behaviour and Organizational Effectiveness Questionnaire (LBOEQ)" and the second instrument was titled Teachers' Perception of Leadership Behaviour Questionnaire (TPPLBQ). The questionnaire was designed to take into consideration the various management patterns adopted by secondary school principals in the course of performing their professional and administrative functions. Each questionnaire was divided into two sections. In LBOEQ. Section A contained the bio-data of respondents which were principals, Section B contained the information on how to respond to questionnaire as the respondents were required to rate the items according to the degree of their agreement or disagreement with the statement and a 10 item question designed to elicit information on principal's perception about leadership behaviour as well as experience and organizational effectiveness.

In TPPLBQ, Section A contained the bio-data of respondents which were teachers, Section B contained the information on how to respond to questionnaire as the respondents were required to rate the items according to the degree of their agreement or disagreement with the statement and a fifteen item question designed to collect information on the behaviour of leaders and organizational effectiveness, sex of leader and organizational effectiveness, qualification of leader and organizational effectiveness.

The instrument was validated by research experts in the areas of educational planning and management within the University of Ado-Ekiti now Ekiti State University, Ado Ekiti.

The study employed both descriptive analysis and hypothesis testing. The descriptive analysis made use of frequency counts: percentage means while the hypothesis generated were tested with the use of chi-square. All the hypothesis were tested with the use of Chi-square $\left(X^{2}\right) 0.05$ level of significance.

\section{Results}

The result of the study is presented as follows:

Table 1. Descriptive Analysis of Respondents'demographic variables.

\begin{tabular}{llllll}
\hline \multirow{2}{*}{$\begin{array}{l}\text { Demographic } \\
\text { Variables }\end{array}$} & \multirow{2}{*}{ Groupings } & \multicolumn{3}{c}{ Principal } & \multicolumn{2}{c}{ Teachers } \\
\cline { 3 - 6 } Sex & Male & 3 & $60 \%$ & 38 & $38 \%$ \\
& Famale & 2 & $40 \%$ & 62 & $62 \%$ \\
& OND & - & - & & \\
& NCE & 1 & $20 \%$ & & \\
Educational & HND & 2 & $40 \%$ & & \\
Qualification & B.A & - & - & & \\
& B.A. (Ed.) & 1 & $20 \%$ & & \\
& B.Sc. & - & - & & \\
Years of & M.Sc. & 1 & $20 \%$ & & \\
teaching/ & Below 10 years & 1 & $40 \%$ & 61 & $61 \%$ \\
administrative & 10-19 years & 2 & $40 \%$ & 25 & $25 \%$ \\
experience & 20-29 years & - & - & 8 & $8 \%$ \\
\hline
\end{tabular}

Table 1 shows that out of 5 principals, $3(60 \%)$ were male while $2(40 \%)$ were female. Distribution according to 
qualifications reveals $1(20 \%)$ had NCE certificate, $2(40 \%)$ are HND holders, $1(20 \%)$ had B.A (Ed.) while $1(20 \%)$ had Masters' degree. $2(40 \%)$ had below 10 years of administrative experiences, $2(20 \%)$ are between $10-19$ years of experience while only $1(20 \%)$ is 30 years and above.

The sample consists of $38(38 \%)$ of male teachers while 62 $(62 \%)$ are females. $61(61 \%)$ have below 10 years of teaching experience, $8(8 \%)$ have between 20 and 29 years of teaching experience, while $6(6 \%)$ have 30 years and above of working experience.

\section{Test of Hypotheses}

Five (5) research hypotheses were tested using chi-square $\left(X^{2}\right)$ statistics at 0.05 level of significance

Hypothesis 1

There is no significant relationship between leadership behaviour and organizational effectiveness in secondary schools.

Table 2. Chi-square $\left(X^{2}\right)$ of leadership behaviour and organizational effectiveness in secondary school.

\begin{tabular}{|c|c|c|c|c|c|c|c|c|}
\hline$S / N$ & Items & SA & $\mathbf{A}$ & D & SD & Df & $X^{2}$ calc & $X^{2}$ table \\
\hline 1 & $\begin{array}{l}\text { The school is effective because there is good communication } \\
\text { between principals and teachers }\end{array}$ & --- & $1(1 \%)$ & $37(37 \%)$ & $62(62 \%)$ & 2 & 56.420 & 5.99 \\
\hline 2 & $\begin{array}{l}\text { Teachers show commitment because the school principal } \\
\text { shows concern for teachers' welfare }\end{array}$ & --- & $9(9 \%)$ & $54(54 \%)$ & 37 (37\%) & 2 & 30.980 & 5.99 \\
\hline 3 & $\begin{array}{l}\text { The school is effective because the the welfare of the students } \\
\text { is taken care of by the principal }\end{array}$ & $2(2 \%)$ & $15(15 \%)$ & $49(49 \%)$ & $34(34 \%)$ & 3 & 51.440 & 7.82 \\
\hline 4 & $\begin{array}{l}\text { The School is effective because the principal allows teachers } \\
\text { and students to take part in the decision making process }\end{array}$ & $5(5 \%)$ & $19(19 \%)$ & $49(49 \%)$ & $27(27 \%)$ & 3 & 40.640 & 7.882 \\
\hline 5 & $\begin{array}{l}\text { The school is effective because principals delegates duties to } \\
\text { subordinates }\end{array}$ & $4(4 \%)$ & $14(14 \%)$ & $51(51 \%)$ & $31(31 \%)$ & 3 & 50.960 & 7.82 \\
\hline
\end{tabular}

$\mathrm{P}<0.05$

Table 2 shows that $1(1 \%)$ of the total sample agreed that the school was effective because there is good communication between principal and teachers while 99 $(99 \%)$ disagreed. $9(9 \%)$ of the total sample agreed that the teachers show commitment because the welfare of students is taken care of by the principal while $83(83 \%)$ disagreed. Also, $24(24 \%)$ of the total sample agreed that the school is effective because the principal allows teachers and students to take part in the decision making process while $76(76 \%)$ disagreed. $18(18 \%)$ of the total sample agreed that the school is effective because the principal delegates duties to subordinates while $82(82 \%)$ disagreed.

The result of chi-square $\left(X^{2}\right)$ analysis shows that $X^{2}$ calculated is greater than $X^{2}$ tabulated at 0.05 level of significance for all items (i.e $56.420>5.99,30.980>5.99$, $51.440>7.82,40.640>7.82,50.960>7.82)$. The null hypothesis is rejected. Therefore, there is a significant relationship between leadership behaviour and organizational effectiveness in secondary school.

Hypothesis 2

There is no significant relationship between sex and organizational effectiveness.

Table 3. Chi-square $\left(X^{2}\right)$ of Sex and organizational effectiveness.

\begin{tabular}{|c|c|c|c|c|c|c|c|c|}
\hline $\mathbf{S} / \mathbf{N}$ & Items & SA & $\mathbf{A}$ & $\mathbf{D}$ & SD & Df & $X^{2}$ calc & $\begin{array}{l}X^{2} \\
\text { table }\end{array}$ \\
\hline 6 & I obey/disobey my principal because of her sex & $48(58 \%)$ & $34(34 \%)$ & $8(8 \%)$ & $10(10 \%)$ & 3 & 44.960 & 7.82 \\
\hline 7 & $\begin{array}{l}\text { I am afraid of participating in decision making because of my } \\
\text { principal's sex }\end{array}$ & $47(47 \%)$ & $46(46 \%)$ & $2(2 \%)$ & $5(5 \%)$ & 3 & 74.160 & 7.82 \\
\hline 8 & The principal sex affect my communication with him & $44(44 \%)$ & $45(45 \%)$ & $8(8 \%)$ & $3(3 \%)$ & 3 & 61.360 & 7.82 \\
\hline 9 & $\begin{array}{l}\text { The school principal has little or no time for job because of his/her } \\
\text { sex }\end{array}$ & $50(50 \%)$ & $41(41 \%)$ & $8(8 \%)$ & $3(3 \%)$ & 3 & 69.040 & 7.82 \\
\hline 10 & The principal delegates duties to a particular sex & $46(46 \%)$ & $40(40 \%)$ & $12(2 \%)$ & $3(3 \%)$ & 3 & 54.560 & 7.82 \\
\hline
\end{tabular}

$\mathrm{P}<0.05$

Table 3 show that $82(82 \%)$ of the total sample agree that they obey/disobey the principal because of his/her sex while $18(18 \%)$ disagreed. Also 93 (93\%) of the total sample agreed that they are afraid of participating in decision making because of their principal's sex while 7 (7\%) disagreed. 89 $(89 \%)$ of the total sample agreed that their principal's sex affect their communication with him/her while 11 (11\%) disagreed.

The result of chi-square $\left(X^{2}\right)$ analysis shows that the $\mathrm{X}^{2}$ calculated is greater than $X^{2}$ tabulated at 0.05 level of significance for all the items (i.e. $44.960>7.82,74.162>$ $7.82,61.360>7.82,69.040>7.82,54.560>7.82)$. The null hypothesis is rejected. Therefore, there is a significant relationship between sex and organizational effectiveness in secondary school.

Hypothesis 3:

There is no significant relationship between qualification of leaders and their behavior towards organizational effectiveness. 
Table 4. Chi-square $\left(x^{2}\right)$ of qualification and organizational effectiveness.

\begin{tabular}{|c|c|c|c|c|c|c|c|c|}
\hline $\mathbf{S} / \mathbf{N}$ & Items & SA & $\mathbf{A}$ & D & SD & Df & $X^{2}$ calc & $X^{2}$ table \\
\hline 11 & $\begin{array}{l}\text { I take instruction from my principal because he/she has higher } \\
\text { certificate }\end{array}$ & $20(20 \%)$ & $28(28 \%)$ & $35(35 \%)$ & $17(17 \%)$ & 3 & 7.920 & 7.82 \\
\hline 12 & The school principal is well trained for his/her job & $2(2 \%)$ & $4(4 \%)$ & $52(52 \%)$ & $42(42 \%)$ & 3 & 79.520 & 7.82 \\
\hline 13 & The principal has managerial skills & $7(7 \%)$ & -- & $45(45 \%)$ & $48(48 \%)$ & 2 & 31.340 & 5.99 \\
\hline 14 & The principal has received in service managerial training & $2(2 \%)$ & $11(11 \%)$ & $58(58 \%)$ & $29(29 \%)$ & 3 & 72.200 & 7.82 \\
\hline 15 & The principal is obeyed because he is most qualified for the job & $9(9 \%)$ & $24(24 \%)$ & $44(44 \%)$ & $23(23 \%)$ & 3 & 24.880 & 7.82 \\
\hline
\end{tabular}

Table 4 shows that $48(48 \%)$ of the total sample take instruction from their principal because he/she has a higher certificate while $52(52 \%)$ disagreed.

$6(6 \%)$ of the total sample agreed that the school principal is well trained for his/her while 94 (94\%) disagreed. 7 (7\%) of the total sample agreed that their principal has managerial skills, while 93(93\%) disagreed. $13(13 \%)$ of the total sample agreed that the principal has received in-service training, while $87(87 \%)$ disagreed. $33(33 \%)$ of the total sample agreed that the principal is obeyed because he is most qualified for the job while 67 (67\%) disagreed.
The result of chi-square $\left(X^{2}\right)$ analysis shows that the $X^{2}$ calculated is greater than $X^{2}$ tabulated at 0.05 level of significance for all the items (i.e $7.920>7.82,79.520>7.82$, $31.340>5.99,73.200>7.82,24.880>7.82)$. The null hypothesis is rejected. Therefore, there is a significant relationship between qualification and organizational effectiveness in secondary school.

Hypothesis 4:

There is no significant relationship in the perception of leaders' behavior by teachers and principals.

Table 5. Chi-square $\left(X^{2}\right)$ of the perception of leaders'behavior by teachers and principal.

\begin{tabular}{|c|c|c|c|c|c|c|c|c|}
\hline $\mathbf{S} / \mathbf{N}$ & Items & $\overline{\text { SA }}$ & A & $\mathbf{D}$ & SD & $\mathbf{D} / \mathbf{f}$ & $\mathrm{X}^{2}$ calc & $\mathrm{X}^{2}$ table \\
\hline 16 & I communicate effectively with both students and teachers & $4(80 \%)$ & $1(20 \%)$ & -- & -- & 1 & 1.800 & 3.84 \\
\hline 17 & Teachers cooperate with me because I show concern for their welfare & $4(80 \%)$ & -- & $1(20 \%)$ & -- & 1 & 1.800 & 3.84 \\
\hline 18 & $\begin{array}{l}\text { The school is effective because I'm concerned about student in } \\
\text { decision making process }\end{array}$ & $4(80 \%)$ & -- & $1(20 \%)$ & -- & 1 & 1.800 & 3.84 \\
\hline 19 & I involve teachers and student in decision making process & $3(60 \%)$ & $2(40 \%)$ & -- & -- & 1 & .200 & 3.84 \\
\hline 20 & I delegate duties subordinate when appropriate & $5(100 \%)$ & -- & -- & -- & 1 & .200 & 3.84 \\
\hline
\end{tabular}

$\mathrm{P}>0.05$

Table 4 shows that $5(100 \%)$ agreed that they communicate effectively with students and teachers.

$4(80 \%)$ of the total sample agreed that teachers cooperate with them because they show concern for their welfare while $1(20 \%)$ disagreed. Also, $4(80 \%)$ of the total sample agreed that the school is effective because they are concerned about students welfare, while $1(20 \%)$ disagreed. $3(60 \%)$ of the total sample agreed that they involve teachers and students in the decision making process while $2(40 \%)$ disagreed.

The result of chi-square $\left(X^{2}\right)$ analysis shows that the $\left(X^{2}\right)$ calculated is less than $\mathrm{x}^{2}$ tabulated at 0.05 level of significance for all the items (i.e. $1.800>3.84$, $1.800>3.84, .200>3.84)$. The null hypothesis is accepted. Therefore, there is no significant relationship between perception of leaders' behavior by teachers and principals.

Hypothesis 5:

There is no significant difference between the experience of leaders and their behavior towards organizational effectiveness.

Table 6. Chi-square $\left(X^{2}\right)$ of experience and organizational effectiveness.

\begin{tabular}{|c|c|c|c|c|c|c|c|c|}
\hline $\mathbf{S} / \mathbf{N}$ & Items & SA & $\mathbf{A}$ & D & SD & Df & $X^{2}$ calc & $X^{2}$ table \\
\hline 21 & I have gained some method of resolving conflict from my experience & $3(60 \%)$ & $2(40 \%)$ & -- & -- & 1 & .200 & 3.84 \\
\hline 22 & $\begin{array}{l}\text { Experience has taught me to communicate effectively with my } \\
\text { subordinates }\end{array}$ & $(240 \%)$ & $3(60 \%)$ & -- & - & 1 & 1.800 & 3.84 \\
\hline 23 & $\begin{array}{l}\text { Past experience has made me to be more effective in discharging my } \\
\text { duties }\end{array}$ & $4(80 \%)$ & $1(20 \%)$ & -- & -- & 1 & 1.800 & 3.84 \\
\hline 24 & I now delegate duties when appropriate because of past experience & $3(60 \%)$ & $3(60 \%)$ & -- & -- & 1 & .200 & 3.84 \\
\hline 25 & $\begin{array}{l}\text { I have learnt to show concern for staff/students welfare from past } \\
\text { experience }\end{array}$ & $4(80 \%)$ & $1(20 \%)$ & -- & -- & 1 & 1.800 & 3.84 \\
\hline
\end{tabular}

Table 6 shows that $5(100 \%)$ of the total sample agreed that they have gained some method of resolving conflict from their experience.

$5(100 \%)$ of the total sample also agreed that experience has taught them to communicate effectively with the subordinates. Also, $5(100 \%)$ of the total sample agreed that past experience has made them more effective in discharging their duties. $5(100 \%)$ of the total sample agreed that they delegate duties when appropriate because of past experience. $5(100 \%)$ of the total sample agreed that they learnt to show concern for staff/ students welfare from past experience.

The result of chi-square $\left(X^{2}\right)$ analysis shows that calculated is greater than $X^{2}$ tabulated at 0.05 level of significance for all the items (i.e. 200>3.84,.200 >3.84, 
$1.800>3.84, .200>3.84,1.800>3.84)$. The null hypothesis is accepted. Therefore, there is no significant relationship between experience of leaders and their behaviour towards organizational effectiveness.

\section{Discussion}

The discussion of the findings of the study is presented as follows:

Hypothesis one was formulated to test the relationship between leadership behaviour and organizational effectiveness.

The finding in this study showed that there is a significant relationship between the leadership behaviour and organizational achievement in secondary schools.

This view was supported by a submission that leadership is a set of interpersonal behaviour designed to influence employees to cooperate in the achievement of group goals. The principal may see himself performing his duty as expected while his leadership behaviour may hinder organizational effectiveness. [5]

Hypothesis two which tested the difference between the behaviour of male and female leaders and organizational effectiveness revealed that there is significant difference in the behaviour of male and female leaders towards organizational effectiveness.

The findings showed that sex of leaders is significant to their behaviour towards the achievement of the school and its overall effectiveness. However, an empirical research conducted and reported by [7] submitted that sex differences in leadership styles are contingent upon the context in which male and female leaders work, as both the type of organization in which the leader works and the setting of the study turn out to be moderators of sex differences in leadership styles. In another study carried out on sex and leadership behaviour, it was noted that the gender - typing of departments did not affect perceived leadership styles. [8]

Leadership as a process of influencing the activities and behaviour of individual or group efforts toward organizational effectiveness. [9]. The sex of a leader hinders this fact about leaders' behaviour.

This finding suggested that sex of a leader goes a long way in determining the types of leadership behaviour he or she exhibits towards the effectiveness of an organization.

Hypothesis five, which tested the difference between the experience of leaders and their behavior towards organizational effectiveness revealed that there is no significant difference between the experience of leaders and organizational effectiveness.

This finding was corroborated with the trait theorist that asserted that leadership was based on two major features i.e. physical and psychological features that differentiate the leader from his followers or other members of the groups. The personal characteristics possessed by successful leaders will help to enhance organizational effectiveness.

The traits like intelligence, self confidence, dependability, industry, initiative, responsibility, courage, originality, supervisory ability, adaptability and human understanding will make the experience of a leader of no effect on organizational effectiveness.

It is implied in above that the principal is to study his job situation and modify the institutional factors so as to achieve maximally in school.

In the motivational theory of [2] the most effective managers were identified to be those who help subordinates to achieve their personal and organizational goals particularly by simulating employee motivation, guidance, support and rewards like money, promotion and some other interesting opportunities for growth and development.

This theory implies that the principal can do a lot to encourage high performance from their teachers by defining position and task-role clearly. This is in line with the submission that leadership is the art of influencing people so that they will strive willingly towards the achievement of goals" [15]. He can also promote staff job performance by showing interest in the staff welfare. This implies that leadership must not only be concerned with structural progress but must also concern about staff well being and progress. This is corroborated by the thoughts that Leadership is not solely concerned with the rational side of organization life but also with the emotions that drive group and organization dynamics. [14].

However, a different view from the above is that leadership needs to be understood in terms of leadership practices and organisational interventions and not just in terms of leader attributes and leader-follower relationships. [13]

It has been observed over time that if a leader adopts this theory, his experience as a leader will not prevent him achieving organizational goals.

\section{Conclusion}

The study revealed that principals occupy a unique position in our educational system. They are educational leaders whose influence is considered crucial in the educational programme of the post-primary school. Principals occupy a key position that what they do or fail to do could make or mar the progress of the school. If principals refuse to carry teachers along in their school administration, much cannot be achieved. The success or failure of an organization depends on the types of leadership behaviour displayed and exhibited by such leaders.

From the findings of this research, it can be concluded that the sex of leaders is significant to their behaviour towards the achievement of the goals of their schools. Also that sex of leaders goes a long in determining the type of leadership behaviour he/she exhibits towards the effectiveness of the organization.

It can further be said that positive perception of teachers about the principal will add more to teachers' efficiency in that they will be psychologically balanced and disposed to do any work assigned to them by the school authority. The study also reveals that the qualification of a leader does not bring 
any difference between his/her behaviour and organizational effectiveness.

It was also concluded that the experience of leaders has no significant relationship to the behaviour. The personal characteristics possessed by leaders will help in enhancing organizational effectiveness.

\section{Recommendations}

It was recommended that school principals should recognize the fact that their interpersonal behaviour is very important in their daily interaction with their teachers towards the effectiveness of the school. School principals must be accommodating and adaptive to human nature. They must embrace collegiate administration and a decision participation in administration. Principals should be sensitive to the needs of their workers. They must always show concern for teachers' problems either personal or official as well as seeing how to achieve educational goals of school and to enhance the effectiveness of the school. They should be careful on how they use power and authority. School principals must not see themselves as custodians of knowledge or regard themselves as lords over the subordinate rather the principal should always welcome and respect the opinions and contributions of the teachers. This will help to enhance organizational effectiveness.

\section{References}

[1] Akomolafe, C. (2001). The Principal Behaviors and Staff Development in Ekiti State Secondary Schools. Unpublished Ph.D. Thesis, Department of Educational Foundation and Management, Faculty of Education, University of Ibadan, Ibadan.

[2] Ankoma-Sey, V. R. and Maina, B. (2019) The Role of Effective Supervision on Academic Performance of Senior High Schools in Ghana. Journal of Arts and Humanities.

[3] Domfeh, K. A., Obuobisa-Darko. T., and Asare, L.O. (2016). Leadership Style and Employee Behaviour: A Reciprocal Relationship. African Research Review. 10 (2). DOI: 10.4314/afrrev.v10i2.1
[4] Duangjai B., and Saowanee T. (2014). The Relationship between the Leadership Style and School Effectiveness in School under the office of Secondary Education Area 20. Procedia - Social and Behavioral Sciences 112 pp 991 - 996

[5] Ibukun, O. (2011). Personality characteristics and principal leadership effectiveness in Ekiti State Nigeria. International Journal of Leadership Studies. vol.6.

[6] Kellerman, B. (2004) "Leadership: warts and all", Harvard Business Review, January 2004, 40-45.

[7] Marloes L. E., and Tineke M. W. (2010). Gender, Context and Leadership Styles: A field Study. Journal of Organisational and occupational psychology. The British Psychological Society.

[8] Marloes L. E., and Tineke M. W. (2004). Gender and Leadership Styles: A Meta-analysis of Research Published in the 1990s. Tilburg University, The Netherlands

[9] Mensah D. K. (2015) Female leadership discourses: The dynamics of teacher performance in basic schools in the upper denkyira east municipality of Ghana. International Journal of Education Learning and Development. 3(1), pp.36-49.

[10] Miller, D.and Sardais, C (2011) A concept of leadership for strategic organization. Sage Publication. DOI: $10.1177 / 1476127011413757$

[11] Mukhtar, R. I., (2019). The Influence of Principals' Leadership Style, The Organizational System And Work Motivation On School Effectiveness. International Journal of Scientific and Technology Research. 8(11) pp 91-104.

[12] Mulliford B., (2003). School Leaders: Challenging Roles and Impact on Teacher and School Effectiveness. OECD Commissioned Paper.

[13] Turnbull J. K, (2011). Leadership in context: Lessons from new leadership theory and current leadership development practice. Commission on Leadership and Management in the NHS. The Kingfund

[14] Turnbull James K, Mann J, Creasy J (2007). 'Leaders as lead learners: a case example of facilitating collaborative leadership learning for school leaders.' Management Learning, 38(1), 79-94.

[15] Udovita, V., (2020). Conceptual Review on Impact of Leadership Style on Employee Performance. International Journal of Business and Management Invention (IJBMI). 9 (9) pp 16-23 